\title{
Inflammation and Infection in Human Cocaine Addiction
}

\author{
Running title: Cocaine and Neuro-immune Interactions
}

\author{
Karen D Ersche ${ }^{1,2 \bowtie}$ and Rainer Döffinger ${ }^{3,4}$
}

1. University of Cambridge, Department of Psychiatry, Cambridge, CB2 0SZ, U.K.

2. Behavioural and Clinical Neuroscience Institute, Cambridge CB2 3EB, U.K.

3. Cambridge University Hospitals NHS Foundation Trust, Department of Clinical Biochemistry and Immunology, Addenbrooke's Hospital, Cambridge CB2 0QQ, U.K.

4. National Institute for Health Research, Cambridge Biomedical Research Centre, Cambridge, UK

\section{$\square$ Correspondence:}

Dr Karen Ersche, University of Cambridge, Department of Psychiatry, Herchel Smith Building for Brain \& Mind Sciences, Cambridge Biomedical Campus, Cambridge CB2 OSZ, UK. Phone: +44 (0)1223 336587, Fax: +44(0)1223 336581, e-mail: ke220@ cam.ac.uk

Word count: 2,755

Abstract: 120

Number of Figures: 1

Number of Tables: 1

Number of References: 54 


\section{Abstract}

Over the past 30 years, the effects of cocaine on the immune system have been subject to research mainly in animals, while relatively little work has been done in humans. This review focuses exclusively on the human work and the related findings in a way that is accessible to neuroscientists. The emerging picture suggests that cocaine may exert some direct effects on lymphocyte responses, as well as, and possibly more importantly, indirect effects via interactions with the sympathetic and neuroendocrine systems. Given the pressing need for more effective treatments for cocaine addiction and the high prevalence of medical complications associated with this disorder, this review leaves no doubt that drug addiction merits a place in the growing field of neuropsychoimmunology.

\section{Introduction}

Cocaine - one of the most widely consumed illicit drugs amongst young adults worldwide is associated with significant harm [1]. Although the negative consequences of regular cocaine use are most noticeable in the domain of psychosocial functioning, attention has been increasingly paid to the wide range of medical complications frequently seen in chronic cocaine users $[2 ; 3]$. Yet, the true scale of the health burden associated with the use of cocaine is only slowly emerging. Many cocaine-related medical complications lack specificity, and may only be recognized once they deteriorate into medical emergencies. However, at this late stage a direct link with cocaine is difficult to establish [4]. A common adverse health consequence in cocaine-addicted individuals is the increased transmission and progression of infectious diseases [4]. Understanding this particular vulnerability for infections may not only help to prevent the worsening of medical problems, but could also open up new avenues for the development of effective medical treatments for cocaine addiction, which are presently still lacking. This review represents an attempt to elucidate the high infection risk in cocaine 
addiction from both a neuroscientific and an immunological perspective, with a particular focus on research in humans. A comprehensive introduction into the field of neuropsychoimmunology would be beyond the scope of this review, but can be found elsewhere [5-7]. Instead, our aim is to give neuroscientists a glimpse into an emerging area of interdisciplinary research that has the potential to broaden and improve our understanding of cocaine addiction.

\section{The neuroscientific perspective:}

\section{Infections due to maladaptive behavior}

For many neuroscientists, inflammation and infection in chronic cocaine users have been regarded as consequential to behaviors that occur in conjunction with cocaine-related changes in brain function. The dopamine system is one of the best studied in cocaine addiction, as it is critically involved in cocaine's highly reinforcing effects, thus determining its addictive properties [8]. As a central nervous stimulant, cocaine acutely increases levels of monoamines (specifically dopamine) by blocking their reuptake [9]. Acute cocaine intoxication is associated with compromised judgement and decision-making abilities, which may facilitate reward-seeking and risk-taking behaviors. Chronic cocaine use has been associated with a variety of neuroadaptive changes, resulting in reduced central dopamine neurotransmission [10;11] and significant abnormalities in brain structure and function [12]. Compromised 'higher level' cognitive processing is thus likely to underlie the erratic and ill-judged behavior patterns frequently seen in cocaine-addicted individuals. No doubt risky behaviors, such as sharing unsterile straws and pipes or engagement in unprotected sex, increase the probability of contracting an infectious disease [13]. Moreover, cocaine users' failure to avoid adversity [14] may not only increase the likelihood for contracting infections even further [15], but also explain the limited success of harm avoidance strategies in the treatment of cocaine addiction 
[16]. A better understanding of the drug's immunomodulatory effects might therefore be critical in developing more effective means of protection.

\section{The immunological perspective:}

\section{Infections due to drug effects on cell-mediated immunity}

Cocaine not only increases monoamine levels in the brain but also in the periphery, where it interacts with immune cells. The neurotransmitter dopamine is thought to play a pivotal role in regulating immunity [17]. Dopamine receptors are expressed on various lymphocyte subpopulations (i.e. T-cells, B-cells and NK-cells), where they contribute to the regulation of proliferation, differentiation and apoptosis of these cells [18]. Through binding to the dopamine transporter in peripheral lymphocytes, cocaine may thus be able to directly modulate immune functions [19]. Dopamine has, therefore, been suggested to act as a mediator between the brain and the immune system, given its involvement in both [20]. Preclinical studies provide support for this hypothesis, showing that experimental lesions of the nigrostriatal dopaminergic system directly result in an increase in the number of circulating T-cells, B-cells, and neutrophil granulocytes in peripheral blood [21]. Clinical observations in neuropsychiatric disorders complement this evidence: Parkinson's disease and schizophrenia, both disorders that are characterized by significant abnormalities in central dopamine function, show significant alterations in the proliferative response of peripheral lymphocytes in these patients [18]. This invites the question of whether the widely studied central nervous dopamine dysfunction in cocaine addiction is also accompanied by changes in the number, proportion and function of $\mathrm{CD} 4+$ and $\mathrm{CD} 8+$ lymphocytes, natural killer $(\mathrm{NK})$ cells, and macrophages in the periphery. 
Although little studied in humans, the picture emerging from the literature suggests that cocaine administration acutely increases the number and activity of distinct lymphocyte populations, including CD4+, CD8+ and NK-cells [22-24]. However, it remains unclear as to whether these changes are long lasting, as reports in actively using cocaine-addicted individuals are inconsistent $[23 ; 25]$. Our own data in stimulant-addicted individuals show significantly higher levels of CD4- and significantly lower levels of NK-cells compared with healthy control volunteers, and no measurable group differences with respect to CD8 and Bcells (Figure 1). Important to note is that these observed changes were not associated with differences in measures of depressed mood, although levels of depression were significantly higher in addicted individuals and depression itself has been associated with changes in immunity. Though perhaps surprising at first glance, these results are consistent with the notion of the dopamine-mediated control of lymphocyte function [26]. For instance, the significant decline in NK-cells could be explained by the suppression of NK-cell proliferation following prolonged dopamine-induced activation [27], which would be a plausible scenario in cocaine addiction. In light of the major role that NK-cells play in anti-viral immune defense, reduced levels of NK-cells may have repercussions on immunity. Furthermore, increased levels of CD4 T-cells would not be unusual following prolonged periods of infection.

Changes in immune regulation may be reflected not only in the cell count, but also in alterations in the cells' capacity to either produce or respond to cytokines. Cytokines are cellsignaling molecules that facilitate communication between cells and regulate immune responses. Changes in cytokine expression may thus impact on immunity. Although several studies identified differences in cytokine concentration in the blood of cocaine-addicted individuals compared with control volunteers [28-33] (Table 1), these results are difficult to 
interpret. Cross-sectional measurements only give a snapshot of participants' current inflammatory status, without providing any details about potential causes or mechanisms underlying the observed deviations. Measurements of cytokine expression in response to cocaine exposure are more informative, as these might elucidate the functional implications of cocaine use on immunity and inflammation.

Though only a few studies have examined blood samples after volunteers had taken cocaine, they consistently report anti-inflammatory effects. Cocaine administration in vivo seems to significantly reduce the synthesis of pro-inflammatory cytokines such as tumor-necrosis factor (TNF) alpha and interleukin (IL) 6 [34;35], irrespective of whether these volunteers had prior experiences with cocaine. By contrast, cocaine-addicted participants in our studies, who are using cocaine almost on a daily basis, show significantly higher levels of IL-6 compared with control volunteers, both in circulating blood (unpublished) as well as in saliva [15]. This suggests that cocaine may acutely exert anti-inflammatory effects but, when used chronically, may have the opposite effect, which increases the risk of systemic inflammation.

The functional implications of altered cytokine secretion can be examined by experimentally activating immune cell populations in vitro. T-cells can be stimulated by the lectin phythohemagglutin (PHA), whereas innate immune cells can be stimulated by the endotoxin lipopolysaccharide (LPS). Cocaine administration in vivo has been shown to acutely alter the cytokine balance between cellular (Th1) and humoral (Th2) immunity by increasing the PHAstimulated secretion of interferon (IFN) gamma and decreasing the secretion of IL-10 [22]. Another study, which also administered cocaine to their volunteers in vivo before challenging their blood in vitro with LPS reported that cocaine had a significant inhibitory effect on the secretion of TNF- $\alpha$ whilst preserving the secretion of IL-6 [34]. However, we could not 
replicate the aforementioned findings in our own data, which we obtained by stimulating blood samples of healthy volunteers in vitro with PHA and LPS both with and without using cocaine as a co-stimulator. One account for the observed discrepancies in results may lie in the nature of conditions for cocaine exposure within different experiments: namely the difference between in vivo versus in vitro exposure. Cocaine exposure in vivo may enable the action of indirect effects of cocaine on neurotransmitters and hormones, which could mediate cocaine's effect on the immune response, in a way that in vitro exposure may not capture [36].

\section{Increasing the risk of infection through drug-induced physiological mechanisms}

The brain and the immune system continuously cross-talk through soluble factors including cytokines, hormones and neurotransmitters, in order to maintain homeostasis. Communication is organized along two main pathways, comprising the autonomic nervous system and the neuroendocrine axis [36]. Disruptions of homeostasis (by either internal or external stressors) activate these two pathways, resulting in increased peripheral levels of catecholamines (specifically noradrenaline) and cortisol respectively, which in turn activate or alter immune function through binding to their matching receptors on immune cells. Innervation of lymphoid tissue by the sympathetic system could be regarded as a direct link between the brain and the immune system [36]. Intriguingly, the effects of cocaine on both the sympathetic nervous and endocrine systems appear to mimic the stress response [35]. The similarities in the effects of stress and cocaine on immune cells are also exemplified by an increase in NK-cells, which has been reported in response to either acute stress or cocaine exposure [23;24;37]. Chronic stress, however, has been associated with a down-regulation in NK-cell activity [38], resembling our data in stimulant-addicted individuals. It is thus conceivable that the observed changes in NK-cells in cocaine-addicted individuals may not 
only be attributable to cocaine's direct effects on immune cells, but may also be due to cocaine's modulatory effects on neuroendocrine hormones [35].

The role of cocaine in the progression of infectious diseases

Our growing knowledge about the immunomodulatory effects of cocaine has raised concerns around whether regular cocaine use may be associated not only with an increased risk for infections, but also with more rapid and severe progression of a contracted infectious disease. An interaction between the drug and a virus have been shown for the human immunodeficiency virus (HIV), but this may well apply to other infections too. One example of such an interaction involves the dopamine transporter (DAT), to which both the HIV-TAT protein and cocaine bind. Whilst cocaine increases extracellular levels of dopamine by inhibiting the DAT and thereby blocking dopamine reuptake, TAT-protein acts as an allosteric modulator of the DAT [39]. The increase in dopamine concentration is thought to result in an augmentation of inflammatory macrophages and greater permeability of the blood-brain-barrier, which in turn promotes the progression of HIV-associated pathology. Importantly, the interactions between cocaine and HIV are complex and are not limited to the DAT. Further mechanisms have been described including cocaine-induced enhancement of HIV transcription and expression [39;40]. Clearly, the use of cocaine during HIV infection worsens the outcome by increasing inflammation, accelerating the progression of the infection and promoting the development of the HIV-associated neurocognitive disorder.

\section{$\underline{\text { Possible clinical implications }}$}


The most obvious clinical consequences resulting from compromised immunity are an increased susceptibility to and accelerated progression of infectious diseases, as well as other medical complications, including cardiovascular and cerebrovascular disorders [41]. The combination of risky behavior patterns, insufficient avoidance of adversity and drug-induced changes to immunity may render chronic cocaine users particularly prone to developing medical complications with a chronic trajectory. Interventions that aim to achieve greater success should therefore not solely rely on users' insight into the health risks associated with their drug use, but rather actively protect them from potential threats to their health that they will likely fail to avoid and that their immune system will struggle to fight.

Not only may cocaine's immunomodulatory effects diminish the users' ability to fight infections, but it is also plausible that these immunomodulatory effects could play a part in the development of addiction itself. Just as the neuroendocrine effects of cocaine have been linked with processes such as sensitization, which enhance cocaine's reinforcing properties [42], cocaine's anti-inflammatory effects might also perpetuate its regular use through mechanisms of negative reinforcement in individuals with systemic inflammation. Any activation of the peripheral immune system leads to increased peripheral concentrations of pro-inflammatory cytokines, which induce a syndrome of sickness behavior characterized by fatigue, anhedonia, anorexia, and depressed mood [43]. The short-term anti-inflammatory effects of cocaine may thus alleviate such inflammation-related or stress-induced discomfort, thereby motivating further use of cocaine.

A further line of enquiry may be to consider what could lie at the roots of an individual's proneness to systemic inflammation. One possible factor might be psychological stress, which can trigger acute inflammatory responses [44]. Childhood trauma and adversity have been 
linked with enhanced inflammatory responsiveness to psychosocial stress [45], and both of these have been linked with later life depression [46]. Such histories are also common in cocaine-dependent individuals, which raises the question as to whether early life-stress mediates the vulnerability to both depression and addiction in these individuals via immunological mechanisms. These individuals, having faced significant adversity early in life $[47 ; 48]$ and thus developed a propensity to increased inflammatory responses, may then be more likely both to suffer from depression and to self-medicate with cocaine [49]. Although the idea of self-medication in the development of cocaine addiction is not new, the antiinflammatory effects of the drug have, to the best of our knowledge, not yet been considered within this context.

\section{$\underline{\text { Possible implications for research }}$}

It is indisputable that the need to improve treatment for cocaine addiction is highly pressing. A better understanding of cocaine's effects on immunity may shed light on new pathways for progress towards meeting this need by revealing mechanisms underpinning the development and chronicity of cocaine addiction, which may serve as targets for future interventions. Although this review only focuses on research conducted in humans, there is also a wealth of animal literature in this field. The present ambiguity of findings thus far in humans highlights the need for further animal research, as well as translational studies in order to apply the knowledge that has been acquired in animals to humans. It is also important that research in humans expands on the animal work by addressing clinically relevant issues such as potential variations in the immunomodulatory effects of cocaine at different stages of the addiction cycle, and how these might determine treatment outcomes. 
As cocaine is most commonly used concurrently with other drugs, in particular with alcohol and opiates, it would also be critical to investigate its immunomodulatory effects in combination with other drugs that affect the immune system in their own way $[6 ; 50]$. As we know from research on the central nervous system, poly-drug use relative to mono-drug use is associated with an amplification of adverse effects on brain structure and function (see Meyerhoff in this issue), and a similar effect may conceivably be mirrored in the changes observed in the immune system. The prolonged use of drugs is another clinically important aspect that requires investigation. Many patients who are seeking treatment have been using cocaine for many years, but the majority of studies only investigate the acute effects of the drug. However, the effects in chronic users are likely to differ and should be considered in research. Furthermore, studies addressing the long-term use of cocaine would be greatly enhanced by assuming a holistic approach, taking into account the multiple interacting systems, including the immune system, which cocaine may exert an influence on.

Turning towards broader considerations, it is worth highlighting the effects of ageing on immune function. Like older people, cocaine users show increased susceptibility to inflammatory diseases and microbial infections [51]. On this basis, an improved understanding of cocaine-related immune adaptations may help to elucidate the relationship between cocaine use, accelerated brain ageing [52] and altered immunity [5]. In a similar vein, it is also possible that cocaine's immunological effects may relate to other notable effects associated with cocaine addiction, such as low body weight and poor sleep quality. Future research should therefore not be restricted to the classical psychotropic actions of addictive drugs, but should also take into consideration the effects at multiple levels in both the brain and the periphery. 
Cocaine and Neuro-immune Interactions

Submission to Current Opinion in Behavioral Sciences

No doubt, the growing interdisciplinary field of neuropsychoimmunology offers much potential for progress in our understanding of brain-immune system interactions, and the implications for psychiatric disorders. This is an exciting new field that is opening up to addiction researchers, bringing opportunities to deepen our understanding and broaden our conceptualization of addiction as a disorder that goes beyond the bounds of the brain as a discrete entity, and thereby potentially paving the way for identifying new targets for the treatment of cocaine addiction.

\section{Acknowledgements}

Our work described in this article was funded by the NIHR Cambridge Biomedical Research Centre. 


\section{Tables}

Table 1: List of studies that have investigated the effects of cocaine use on the human immune system over the past 30 years, which are highly heterogeneous in terms of the cell types/products being studied (cells, cytokines, chemokines), procedures conducted (in vivo / in vitro), type of stimulation being used ( $\mathrm{T}$-cell stimulation / innate), and composition of the samples analyzed (patients, healthy volunteers, level of dependency, state of abstinence).

\begin{tabular}{|c|c|c|c|}
\hline Authors & Groups & Measures & Key Findings \\
\hline $\begin{array}{l}\text { Moreira et al } \\
2016[28]\end{array}$ & $\begin{array}{l}\text { - } 12 \text { self-reported cocaine } \\
\text { users (abstinent) } \\
\text { - } 24 \text { healthy controls }\end{array}$ & Serum IL6, IL10 & $\begin{array}{l}\text { IL6: Cocaine }>\text { Control } \\
\text { IL10: Cocaine }<\text { Control }\end{array}$ \\
\hline $\begin{array}{|lr|}\text { Araos et al } \\
2015[30]\end{array}$ & $\begin{array}{l}\text { - } 82 \text { chronic cocaine users } \\
\text { (abstinent) with co-morbid } \\
\text { alcohol use disorder } \\
\text { - } 65 \text { healthy controls }\end{array}$ & $\begin{array}{l}\text { Plasma TNF } \alpha, \quad \text { IL1 } \beta, \quad \text { IL6, CX3CL1 / } \\
\text { fractalkine, CCL2 / MCP-1, }\end{array}$ & $\begin{array}{l}\text { TNF } \alpha, \text { CCL2 / MCP-1 } \\
\text { CXCL12 / SDF-1: } \\
\text { Cocaine < Control }\end{array}$ \\
\hline \begin{tabular}{|l|} 
Ersche et al \\
$2014[15]$
\end{tabular} & $\begin{array}{l}\text { - } 31 \text { cocaine-dependent men } \\
\text { (not abstinent) } \\
\text { - } 30 \text { healthy male controls }\end{array}$ & $\begin{array}{l}\text { Saliva Il1 } \beta, \text { IL6, IL8, IL10, IL12p70, TNF } \alpha, \text { IFN } \gamma \\
\text { Serial sampling: pre/post provocation } \\
\text { ( } 2 \text { conditions: disgust-evoking, neutral) } \\
\text { Recordings: skin conductance, response time } \\
\text { Questionnaires: attitudes towards disgust and } \\
\text { hygiene behaviors }\end{array}$ & $\begin{array}{l}\text { I16 baseline: } \\
\text { Cocaine > Control } \\
\text { IL6 disgust provocation: } \\
\text { Cocaine > Control }\end{array}$ \\
\hline 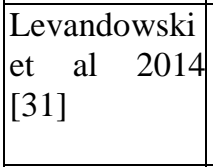 & $\begin{array}{l}\text { - } 44 \text { cocaine-dependent } \\
\text { women (abstinent) } \\
\text { - } 25 \text { female healthy controls }\end{array}$ & $\begin{array}{l}\text { Plasma TNF } \alpha, \text { sTNFRI, sTNFRII, TWEAK, } \\
\text { TRAIL } \\
\text { Questionnaires: childhood trauma, severity of } \\
\text { tobacco smoking }\end{array}$ & $\begin{array}{l}\text { Group differences } \\
\text { mediated by history of } \\
\text { childhood trauma. }\end{array}$ \\
\hline \begin{tabular}{|l|} 
Narvaez et al \\
2013 [29]
\end{tabular} & $\begin{array}{l}\text { - } 37 \quad \text { cocaine-dependent } \\
\text { individuals (abstinent) } \\
\text { - } 27 \text { healthy controls }\end{array}$ & $\begin{array}{l}\text { Serum Il1 } \beta, \text { IL6, TNF } \alpha, \text { IL8, IL10, IL12p70, } \\
\text { BDNF, TBARS, PCC }\end{array}$ & $\begin{array}{l}\text { IL1 } 1 \beta, \text { TNF } \alpha, \text { BDNF: } \\
\text { Cocaine > Control }\end{array}$ \\
\hline $\begin{array}{l}\text { Fox et al } \\
2012[53]\end{array}$ & $\begin{array}{l}\text { - } 28 \quad \text { cocaine-dependent } \\
\text { individuals (abstinent) } \\
\text { - } 27 \text { social drinking controls }\end{array}$ & $\begin{array}{l}\text { Plasma TNF } \alpha \text {, IL10, IL1ra } \\
\text { Serial sampling: pre and post mental imagery } \\
\text { ( } 2 \text { conditions: stress, neutral) } \\
\text { Additional measurements: drug craving }\end{array}$ & $\begin{array}{l}\text { IL10 baseline } \\
\text { Cocaine < Control } \\
\text { TNFa following stres } \\
\text { imagery: } \\
\text { Cocaine > Control }\end{array}$ \\
\hline $\begin{array}{l}\text { Loftis et al } \\
2011 \text { [54] }\end{array}$ & $\begin{array}{l}\text { - } 20 \text { methamphetamine- } \\
\text { dependent (abstinent) } \\
\text { - } 20 \text { healthy controls }\end{array}$ & $\begin{array}{l}\text { Plasma IL1 } \beta, \text { IL2, IL6, IL10, TNF } \alpha, \text { MCP-1, } \\
\text { MIP-1 } \alpha, \text { MIP-1 } \beta \text {, ICAM-1 }\end{array}$ & $\begin{array}{l}\text { No significant group } \\
\text { differences. }\end{array}$ \\
\hline $\begin{array}{lrr}\text { Irwin et al } \\
2007[34]\end{array}$ & $\begin{array}{l}\text { - } 19 \text { cocaine-dependent men } \\
\text { (abstinent) } \\
\text { - } 19 \text { healthy male controls }\end{array}$ & $\begin{array}{l}\text { Plasma TNF } \alpha \text {, IL6 } \\
\text { In vivo: } 40 \mathrm{mg} \text { cocaine IV and placebo IV } \\
\text { Serial sampling: pre and every } 4 \text { hours post } \\
\text { treatment } \\
\text { In vitro: LPS stimulation } \\
\text { Additional measurements: heart rate variability }\end{array}$ & $\begin{array}{l}\text { TNF- } \alpha \text { baseline: } \\
\text { Cocaine < Control } \\
\text { TNF } \alpha \text { and IL6 pos } \\
\text { treatment: } \\
\text { Cocaine < Placebo } \\
\text { LPS-stimulated TNF } \alpha \text { : } \\
\text { Cocaine < Placebo } \\
\end{array}$ \\
\hline $\begin{array}{|lr|}\text { Rios-Olivares } \\
\text { et } & \text { al } \\
{[33]}\end{array}$ & $\begin{array}{l}\text { - } 30 \text { cocaine and heroin } \\
\text { dependent individuals with } \\
\text { hepatitis } \mathrm{C} \text { (not abstinent) } \\
\text { - } 30 \text { healthy controls without } \\
\text { hepatitis } \mathrm{C}\end{array}$ & $\begin{array}{l}\text { Plasma + supernatants TNF } \alpha, \text { IFN } \gamma, \text { IL1 } \beta, \text { IL2, } \\
\text { IL4, IL6, IL10 } \\
\text { In vitro: PHA and PAI stimulation }\end{array}$ & $\begin{array}{l}\text { TNF } \alpha, \text { IFN } \gamma, \text { IL2,IL4, } \\
\text { IL6, } \\
\text { (unstimulated): } \\
\text { Cocaine > Control }\end{array}$ \\
\hline $\begin{array}{l}\text { Halpern et al } \\
2003[35]\end{array}$ & $\begin{array}{l}\text { - } 2 \quad x \quad 15 \quad \text { cocaine users } \\
\text { (not dependent, abstinent) }\end{array}$ & $\begin{array}{l}\text { Plasma IL6, cortisol, ACTH, DHEA, cocaine } \\
\text { levels } \\
\text { In vivo: either IV } 0.4 \mathrm{mg} / \mathrm{kg} \text { cocaine or placebo } \\
\text { Serial sampling: pre / } 2 \text { hours post treatment } \\
\text { Additional measurements: endocrine responses }\end{array}$ & $\begin{array}{l}\text { IL6 baseline: } \\
\text { No group differences } \\
\text { IL6 post treatment: } \\
\text { Cocaine < Placebo }\end{array}$ \\
\hline $\begin{array}{|ll|}\text { Gan et } & \text { al } \\
1998 & {[22]}\end{array}$ & $\begin{array}{l}\text { - } 15 \text { cocaine-dependent } \\
\text { individuals (not abstinent) } \\
\text { - } 4 \text { healthy blood donors } \\
\end{array}$ & $\begin{array}{l}\text { Plasma INF } \gamma, \text { TNF } \alpha, I L 1 \beta, \text { IL2, IL6 IL10, } \\
\text { IL12 } \\
\text { Lymphocytes profile: CD4+, CD8+, NK-cells }\end{array}$ & $\begin{array}{l}\text { INF } \text { : } \text { Cocaine }>\text { baseline } \\
\text { IL10: } \text { Cocaine }<\text { baseline } \\
\text { In } \quad \text { vitro } \quad \text { stimulatio }\end{array}$ \\
\hline
\end{tabular}


Cocaine and Neuro-immune Interactions

Ersche \& Döffinger

Submission to Current Opinion in Behavioral Sciences

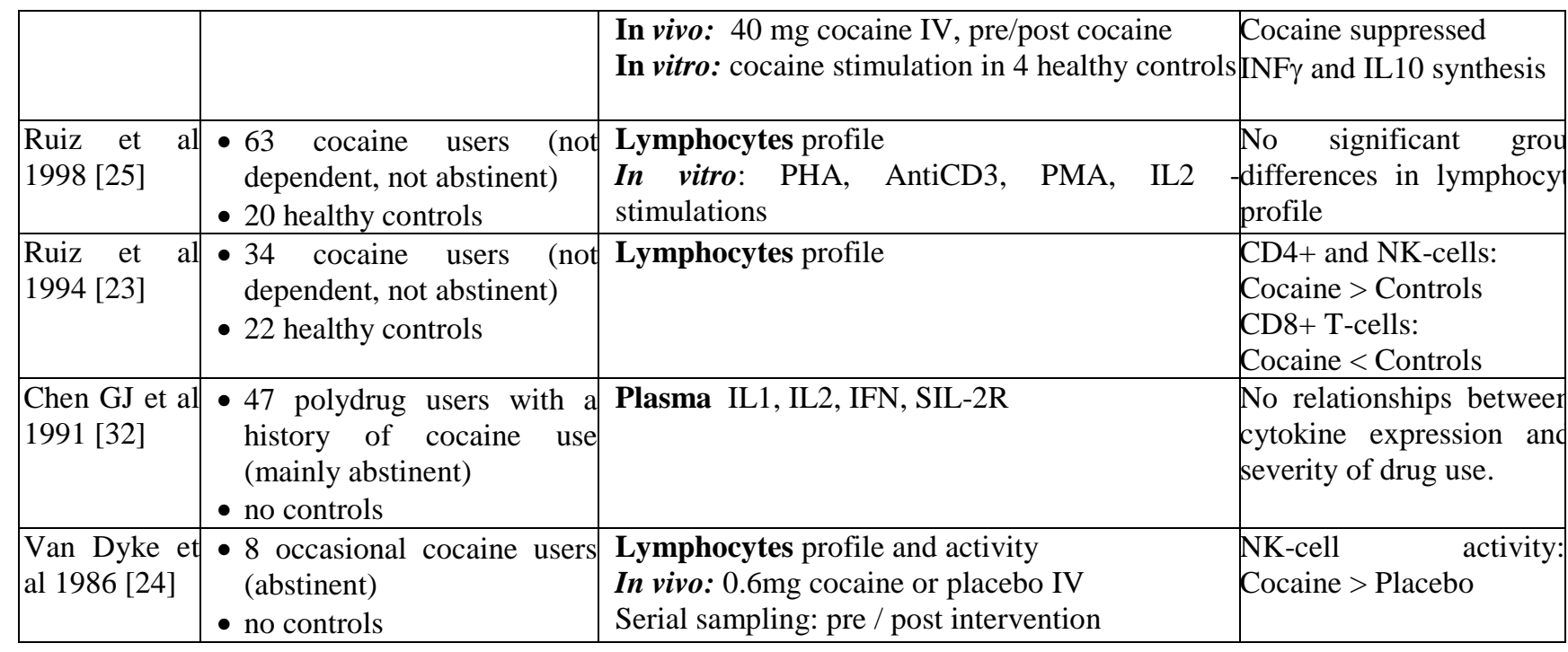




\section{Figures}
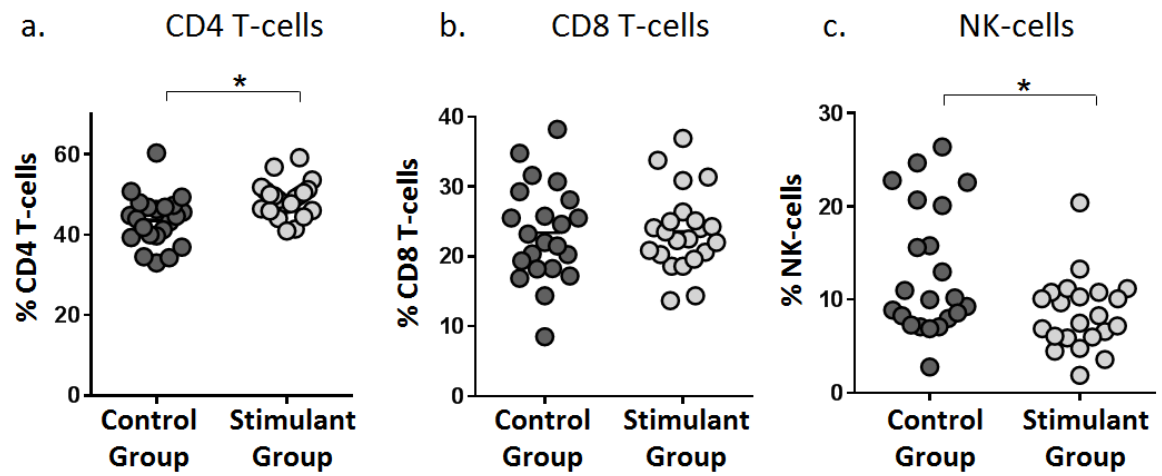

$$
\text { d. B-cells }
$$

Figure 1: Comparisons of T-cells, NK-cells and B-cells between 22 actively using stimulantdependent individuals and 22 matched healthy control volunteers. (a) The percentage of CD4 Tcells was significantly increased in the stimulant-dependent group compared with control volunteers $\left(\mathrm{t}_{42}=3.21, p=0.003\right)$. (b) The percentage of CD8 T-cells $\left(\mathrm{t}_{42}=0.11, p=0.916\right)$ and the $\mathrm{CD} 4 / \mathrm{CD} 8$ ratio did not significantly differ between the groups $\left(\mathrm{t}_{42}=0.58, p=0.568\right)$. (c) The percentage of NK-cells is significantly reduced in the stimulant-dependent group $\left(\mathrm{t}_{42}=2.69, p=\right.$ 0.010) compared with the control group. (d) No differences were found with respect to the percentage of B-cells $\left(t_{42}=1.79, p=0.081\right)$. 


\section{References}

A text of particular interest, published within the period of review, have been highlighted as:

$*$ of special interest, and ** of outstanding interest

1. Jones L, Bartes G, Bellis M, Beynon C, Duffy P, Evans-Brown M, Mackridge A, McCoy E, Sumnall H, McVeigh J: A summary of the health harms of drugs. London: U.K. Department of Health; 2011.

2. EMCDDA: Cocaine and Crack Cocaine: A Growing Public Health Problem. Lisbon, Portugal: European Monitoring Centre for Drugs and Drug Addiction; 2007.

3. Dinis-Oliveira RJ, Carvalho F, Duarte JA, Proenca JB, Santos A, Magalhaes T: Clinical and forensic signs related to cocaine abuse. Curr Drug Abuse Rev 2012, 5:64-83.

4. Mena G, Giraudon I, Alvarez E, Corkery JM, Matias J, Grasaasen K, Llorens N, Griffiths P, Vicente J: Cocaine-Related Health Emergencies in Europe: A Review of Sources of Information, Trends and Implications for Service Development. European Addiction Research 2013, 19:74-81.

5. Clark KH, Wiley CA, Bradberry CW: Psychostimulant Abuse and Neuroinflammation: Emerging Evidence of Their Interconnection. Neurotox Res 2013, 23:174-188.

6. Coller JK, Hutchinson MR: Implications of central immune signaling caused by drugs of abuse: Mechanisms, mediators and new therapeutic approaches for prediction and treatment of drug dependence. Pharmacol Therapeut 2012, 134:219-245.

7. Marasco CC, Goodwin CR, Winder DG, Schramm-Sapyta NL, Mclean JA, Wikswo JP: Systems-level view of cocaine addiction: The interconnection of the immune and nervous systems. Experimental Biology and Medicine 2014, 239:1433-1442.

** This article provides a comprehensive review of the current knowledge in the field. It covers the effects of cocaine on cell-mediated immunity and humoral immunity as well as the involvement of monoamines and the sigma receptor in cocaine mediated immunomodulation.

8. Volkow ND, Fowler JS, Wang GJ, Swanson JM: Dopamine in drug abuse and addiction: results from imaging studies and treatment implications. Mol Psychiatr 2004, 9:557-569.

9. Johanson CE, Fischman MW: The Pharmacology of Cocaine Related to Its Abuse. Pharmacol Rev 1989, 41:3-52.

10. Martinez D, Broft A, Foltin RW, Slifstein M, Hwang DR, Huang YY, Perez A, Frankel WG, Cooper T, Kleber HD, Fischman MW, Laruelle M: Cocaine dependence and $\mathrm{D} 2$ receptor availability in the functional subdivisions of the striatum: Relationship with cocaine-seeking behavior. Neuropsychopharmacol 2004, 29:1190-1202. 
11. Martinez D, Greene K, Broft A, Kumar D, Liu F, Narendran R, Slifstein M, Van Heertum R, Kleber HD: Lower Level of Endogenous Dopamine in Patients With Cocaine Dependence: Findings From PET Imaging of D2/D3 Receptors Following Acute Dopamine Depletion. Am J Psychiat 2009, 166:1170-1177.

12. Ersche KD, Williams GB, Robbins TW, Bullmore ET: Meta-analysis of structural brain abnormalities associated with stimulant drug dependence and neuroimaging of addiction vulnerability and resilience. Curr Opin Neurobiol 2013, 25:615-624.

13. Howe CJ, Fuller CM, Ompad DC, Galea S, Koblin B, Thomas D, Vlahov D: Association of sex, hygiene and drug equipment sharing with hepatitis $C$ virus infection among non-injecting drug users in New York City. Drug Alcohol Depen 2005, 79:389-395.

14. Ersche KD, Gillan CM, Jones PS, Williams GB, Ward LHE, Luijten M, de Wit S, Sahakian BJ, Bullmore ET, Robbins TW: Carrots and Sticks Fail to Change Behavior in Cocaine Addiction. Science 2016, 352:1468-1471.

15. Ersche KD, Hagan CC, Smith DG, Abbott S, Jones PS, Apergis-Schoute AM, Döffiner R: Aberrant Disgust Responses and Immune Reactivity in CocaineDependent Men. Biol Psychiat 2014, 75:140-147.

16. Fischer B, Blanken P, Da Silveira D, Gallassi A, Goldner EM, Rehm J, Tyndall M, Wood E: Effectiveness of secondary prevention and treatment interventions for crack-cocaine abuse: A comprehensive narrative overview of English-language studies. Int J Drug Policy 2015, 26:352-363.

17. Basu S, Dasgupta PS: Dopamine, a neurotransmitter, influences the immune system. J Neuroimmunol 2000, 102:113-124.

18. Levite M: Dopamine and $\mathbf{T}$ cells: dopamine receptors and potent effects on $\mathbf{T}$ cells, dopamine production in $T$ cells, and abnormalities in the dopaminergic system in $\mathbf{T}$ cells in autoimmune, neurological and psychiatric diseases. Acta Physiologica 2016, 216:42-89.

19. Sarkar C, Basu B, Chakroborty D, Dasgupta PS, Basu S: The immunoregulatory role of dopamine: An update. Brain Behav Immun 2010, 24:525-528.

** This excellent and concise review on the effects of dopamine on immune function is easily accessible for neuroscientist. It extends an earlier review by Basu et al (2002).

20. Pacheco R, Contreras F, Zouali M: The dopaminergic system in autoimmune diseases. Frontiers in Immunology 2014, 5:1-17.

21. Engler H, Doenlen R, Riether C, Engler A, Niemi MB, Besedovsky HO, del Rey A, Pacheco-Lopez G, Feldon J, Schedlowski M: Time-dependent alterations of peripheral immune parameters after nigrostriatal dopamine depletion in a rat model of Parkinson's disease. Brain Behav Immun 2009, 23:518-526. 
22. Gan X, Zhang L, Newton T, Chang SL, Ling W, Kermani V, Berger O, Graves MC, Fiala M: Cocaine Infusion Increases Interferon-[gamma] and Decreases Interleukin-10 in Cocaine-Dependent Subjects. Clin Immunol Immunop 1998, 89:181-190.

23. Ruiz P, Cleary T, Nassiri TM, Steele B: Human T-Lymphocyte Subpopulation and Nk Cell Alterations in Persons Exposed to Cocaine. Clin Immunol Immunop 1994, 70:245-250.

24. Van Dyke C, Stesin A, Jones R, Chuntharapai A, Seaman W: Cocaine increases natural killer cell activity. J Clin Invest 1986, 77:1387-1390.

25. Ruiz P, Berho M, Steele BW, Hao L: Peripheral human T lymphocyte maintenance of immune functional capacity and phenotypic characteristics following in vivo cocaine exposure. Clin Immunol Immunop 1998, 88:271-276.

26. Pacheco R, Prado CE, Barrientos MJ, Bernales $\mathrm{S}$ : Role of dopamine in the physiology of T-cells and dendritic cells. Journal of Neuroimmunology 2009, 216:819.

27. Mikulak J, Bozzo L, Roberto A, Pontarini E, Tentorio P, Hudspeth K, Lugli E, Mavilio D: Dopamine Inhibits the Effector Functions of Activated NK Cells via the Upregulation of the D5 Receptor. Journal of Immunology 2014, 193:2792-2800.

28. Moreira FP, Carvalho Medeiros JR, Lhullier AC, de Mattos Souza LD, Jansen K, Portela LV, Lara DR, da Silva RA, Wiener CD, Oses JP: Cocaine abuse and effects in the serum levels of cytokines IL-6 and IL-10. Drug Alcohol Depen 2016, 158:181-185.

29. Narvaez JC, Magalhaes PV, Fries GR, Colpo GD, Czepielewski LS, Vianna P, Bog Chies JA, Rosa AR, Von Diemen L, Vieta E, Pechansky F, Kapczinski F: Peripheral toxicity in crack cocaine use disorders. Neurosci Lett 2013, 544:80-84.

30. Araos P, Pedraz M, Serrano A, Lucena M, Barrios V, Garcia-Marchena N, CamposCloute R, Ruiz JJ, Romero P, Suarez J, Baixeras E, de la Torre R, Montesinos J, Guerri C, Rodriguez-Arias M, Minarro J, Martinez-Riera R, Torrens M, Chowen JA, Argente J, Mason BJ, Pavon FJ, Rodriguez de Fonseca F: Plasma profile of proinflammatory cytokines and chemokines in cocaine users under outpatient treatment: influence of cocaine symptom severity and psychiatric co-morbidity. Addict Biol 2015, 20:756-772.

31. Levandowski ML, Viola TW, Wearick-Silva LE, Wieck A, Tractenberg SG, Brietzke E, Bauer ME, Teixeira AL, Grassi-Oliveira R: Early life stress and tumor necrosis factor superfamily in crack cocaine withdrawal. Journal of Psychiatric Research 2014, 53:180-186.

32. Chen GJ, Pillai R, Erickson JR, Martinez F, Estrada AL, Watson RR: Cocaine Immunotoxicity - Abnormal Cytokine Production in Hispanic Drug-Users. Toxicology Letters 1991, 59:81-88. 
33. Rios-Olivares E, Vila LM, Reyes JC, Rodriguez JW, Colon JH, Pagan NO, Marrero A, Rios-Orraca ZM, Boukli NM, Shapshak P, Robles RR: Impaired cytokine production and suppressed lymphocyte proliferation activity in $\mathrm{HCV}$-infected cocaine and heroin (speedball) users. Drug Alcohol Depen 2006, 85:236-243.

34. Irwin MR, Olmos L, Wang M, Valladares EM, Motivala SJ, Fong T, Newton T, Butch A, Olmstead R, Cole SW: Cocaine Dependence and Acute Cocaine Induce Decreases of Monocyte Proinflammatory Cytokine Expression across the Diurnal Period: Autonomic Mechanisms. J Pharmacol Exp Ther 2007, 320:507-515.

* The study described in this article investigates the link between the immune system and the autonomic system by monitoring the responses to cocaine in cocainedependent men using serial assessments of cytokine production and heart-rate variability measurements. This is an excellent example of how the autonomic system mediates the immunomodulatory effects of cocaine.

35. Halpern JH, Sholar MB, Glowacki J, Mello NK, Mendelson JH, Siegel AJ: Diminished Interleukin-6 Response to Proinflammatory Challenge in Men and Women after Intravenous Cocaine Administration. J Clin Endocrinol Metab 2003, 88:1188-1193.

* This study investigates the mediating effects of the endocrine system on the effects of cocaine on the immune system by administering cocaine to healthy individuals' immune system in a placebo-controlled manner.

36. Sternberg EM: Neural regulation of innate immunity: a coordinated nonspecific host response to pathogens. Nat Rev Immunol 2006, 6:318-328.

** This review provides an excellent introduction for the non-immunology on the relationship between the central nervous and immune systems.

37. Pike JL, Smith TL, Hauger RL, Nicassio PM, Patterson TL, McClintick J, Costlow C, Irwin MR: Chronic life stress alters sympathetic, neuroendocrine, and immune responsivity to an acute psychological stressor in humans. Psychosom Med 1997, 59:447-457.

38. Dallman MF: Stress update. Trends in Endocrinology \& Metabolism 1993, 4:62-69.

39. Dahal S, Chitti SVP, Nair MPN, Saxena SK: Interactive effects of cocaine on HIV infection: implication in HIV-associated neurocognitive disorder and neuroAIDS. Frontiers in Microbiology 2015, 6.

40. Swepson C, Ranjan A, Balasubramaniam M, Pandhare J, Dash C: Cocaine Enhances HIV-1 Transcription in Macrophages by Inducing p38 MAPK Phosphorylation. Frontiers in Microbiology 2016, 7.

41. Restrepo CS, Rojas CA, Martinez S, Riascos R, Marmol-Velez A, Carrillo J, Vargas D: Cardiovascular complications of cocaine: Imaging findings. Emergency Radiology 2009, 16:11-19. 
42. Goeders NE: The HPA axis and cocaine reinforcement. Psychoneuroendocrino 2002, 27:13-33.

43. Dantzer R, Kelley KW: Twenty years of research on cytokine-induced sickness behavior. Brain, Behavior, and Immunity 2007, 21:153-160.

44. Black PH: Stress and the inflammatory response: A review of neurogenic inflammation. Brain Behav Immun 2002, 16:622-653.

45. Carpenter LL, Gawuga CE, Tyrka AR, Lee JK, Anderson GM, Price LH: Association between Plasma IL-6 Response to Acute Stress and Early-Life Adversity in Healthy Adults. Neuropsychopharmacol 2010, 35:2617-2623.

46. Pace TWW, Mletzko TC, Alagbe O, Musselman DL, Nemeroff CB, Miller AH, Heim $\mathrm{CM}$ : Increased stress-induced inflammatory responses in male patients with major depression and increased early life stress. Am J Psychiat 2006, 163:16301633.

47. Narvaez JCM, Magalhaes PVS, Trindade EK, Vieira DC, Kauer-Sant'Anna M, Gama CS, von Diemen L, Kapczinski NS, Kapczinski F: Childhood trauma, impulsivity, and executive functioning in crack cocaine users. Compr Psychiat 2012, 53:238244.

48. Ersche KD, Turton AJ, Chamberlain SR, Müller U, Bullmore ET, Robbins TW: Cognitive dysfunction and anxious-impulsive personality traits are endophenotypes for drug dependence. Am J Psychiat 2012, 169:926-936.

49. Weiss RD, Griffin ML, Mirin SM: Drug Abuse as Self-Medication for Depression: An Empirical Study. Am J Drug Alcohol Abuse 1992, 18:121-129.

50. Friedman H, Pross S, Klein TW: Addictive drugs and their relationship with infectious diseases. Fems Immunol Med Mic 2006, 47:330-342.

51. Dorshkind K, Montecino-Rodriguez E, Signer RAJ: The ageing immune system: is it ever too old to become young again? Nat Rev Immunol 2009, 9:57-62.

52. Ersche KD, Jones PS, Williams GB, Robbins TW, Bullmore ET: Cocaine dependence: a fast-track for brain ageing? Mol Psychiatr 2013, 18:134-135.

53. Fox HC, D'Sa C, Kimmerling A, Siedlarz KM, Tuit KL, Stowe R, Sinha R: Immune system inflammation in cocaine dependent individuals: implications for medications development. Hum Psychopharm Clin 2012, 27:156-166.

54. Loftis JM, Choi D, Hoffman W, Huckans MS: Methamphetamine Causes Persistent Immune Dysregulation: A Cross-Species, Translational Report. Neurotox Res 2011, 20:59-68. 